\title{
Rockfall monitoring by Terrestrial Laser Scanning - case study of the basaltic rock face at Castellfollit de la Roca (Catalonia, Spain)
}

\author{
A. Abellán, J. M. Vilaplana, J. Calvet, D. García-Sellés, and E. Asensio \\ RISKNAT research group and GEOMODELS Institute, Dept. of Geodynamics and Geophysics, University of Barcelona, \\ C/Martí i Franquès s/n. 08028, Barcelona, Spain
}

Received: 6 July 2009 - Revised: 25 October 2010 - Accepted: 17 December 2010 - Published: 15 March 2011

\begin{abstract}
This case study deals with a rock face monitoring in urban areas using a Terrestrial Laser Scanner. The pilot study area is an almost vertical, fifty meter high cliff, on top of which the village of Castellfollit de la Roca is located. Rockfall activity is currently causing a retreat of the rock face, which may endanger the houses located at its edge. TLS datasets consist of high density 3-D point clouds acquired from five stations, nine times in a time span of 22 months (from March 2006 to January 2008). The change detection, i.e. rockfalls, was performed through a sequential comparison of datasets. Two types of mass movement were detected in the monitoring period: (a) detachment of single basaltic columns, with magnitudes below $1.5 \mathrm{~m}^{3}$ and (b) detachment of groups of columns, with magnitudes of 1.5 to $150 \mathrm{~m}^{3}$. Furthermore, the historical record revealed (c) the occurrence of slab failures with magnitudes higher than $150 \mathrm{~m}^{3}$. Displacements of a likely slab failure were measured, suggesting an apparent stationary stage. Even failures are clearly episodic, our results, together with the study of the historical record, enabled us to estimate a mean detachment of material from 46 to $91.5 \mathrm{~m}^{3}$ year $^{-1}$. The application of TLS considerably improved our understanding of rockfall phenomena in the study area.
\end{abstract}

\section{Introduction}

A rockfall, which is a fragment of rock detached by sliding, toppling or falling, falls along a vertical or sub-vertical cliff and proceeds down slope by bouncing, rolling or sliding (Varnes, 1978). Minor scale rockfalls (up to several hundred cubic meters) are the most frequent type of landslide on steep slopes in mountain areas (Copons and Vilaplana,

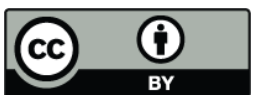

Correspondence to: A. Abellán (antonio.abellan@ub.edu)
2008), marine cliffs (Rosser et al., 2005b) and rock faces. Magnitude, frequency, spatial location and velocity of the rockfalls are the main parameters for a rockfall hazard assessment (Varnes, 1978).

The possibility of acquiring datasets of the terrain surface with a high accuracy and high spatial resolution, either using laser, optical or radar sensors mounted on terrestrial, aerial or satellite equipment are currently opening up new ways to visualize, model and interpret Earth surface processes. Ground-based sensors, e.g. Terrestrial Laser Scanners (TLS), obtain their maximum resolution on surfaces perpendicularly oriented to the beam incidence angle, such as mountainous rock faces, marine cliffs, etc. TLS is one of the most promising remote sensing techniques for rock slope characterization and monitoring because of its capability to accurately acquire dense three-dimensional (3-D) coordinates of the terrain (e.g. Biasion et al., 2005; Bauer et al., 2005; Oppikofer et al., 2008). A recent review of these techniques can be found in SafeLand Deliverable 4.1 (2010) and Jaboyedoff et al. (2010). TLS is currently being used by different groups in the monitoring and hazard assessment of slope movements. Its main applications in the field of rock slope studies concern the characterization of 3-D discontinuities (Jaboyedoff et al., 2007; Sturzenegger and Stead, 2009) and change detection, e.g. rockfalls (Rosser et al., 2005a; Lim et al., 2006; Abellán et al., 2010), rock avalanches (Dunning et al., 2009) and soil slides (Teza et al., 2007; Monserrat and Crosetto, 2008; Prokop and Panholzer, 2009). Recent studies highlight the applicability of TLS to the estimation of the retreat rates of different rock slopes: Rabatel et al. (2008) quantified the volume of the main rockfalls on the east face of the Tour Ronde, Mont Blanc massif; Oppikofer et al. (2008) discussed the movement of various blocks and the final collapse of a rock spur on the eastern flank of the Eiger peak (Swiss Alps); Lim et al. (2009) studied the erosion rates of a rocky coastal cliff at Staithes, North Yorkshire (UK) and the influence of environmental variables during a two year monitoring

Published by Copernicus Publications on behalf of the European Geosciences Union. 

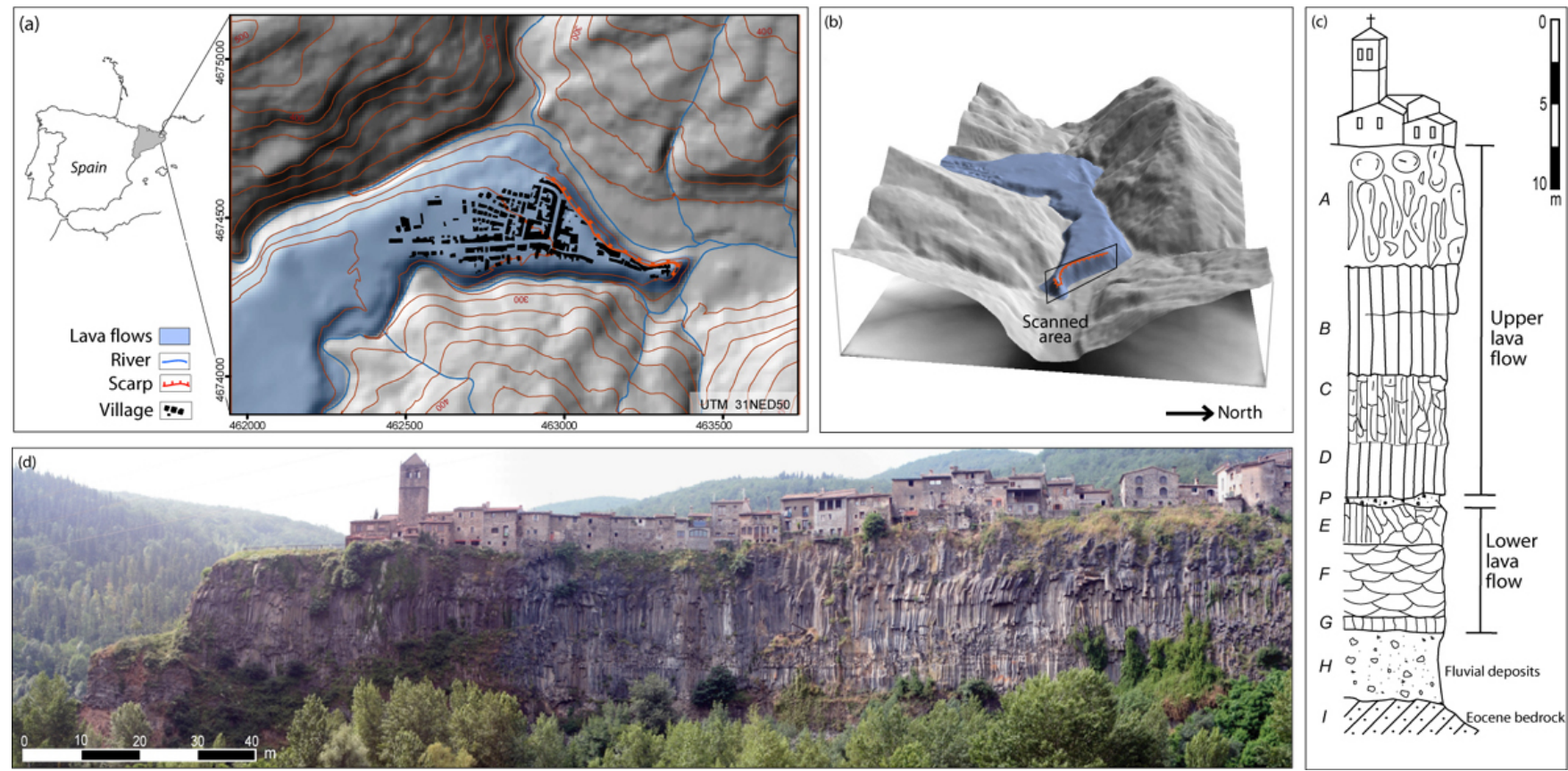

Fig. 1. (a) Location of the village and the basaltic formation at Castellfollit de la Roca (Garrotxa Volcanic Field, NE Spain). (b) Perspective view with indication of the scanned rockface. (c) Synthetic stratigraphic sequence modified from Pallí and Trilla (1976). Thickness $\sim 45 \mathrm{~m}$. See Table 1 for a description of the geological levels (from A to I). (d) Panoramic view of the north face of the basaltic formation at Castellfollit de la Roca. Houses located on the edge of the cliff are visible.

period. Finally, Dewez et al. (2009) analyzed the erosion rates on a 700-m long coastal chalk cliff in Normandy. We provide here a case study of the application of TLS technology to the monitoring of a basaltic rock face, at the top of which the village of Castellfollit de la Roca is located (Catalonia, Spain, Fig. 1a). The interest of this study lies in the application of this technique in urban areas since little has been published before on this topic (e.g. Pieraccini et al., 2006).

From a geomorphological point of view, rockfalls currently constitute the main failure mechanism at the rock face. The rockfall and hence the rock face retreat could pose an important risk to houses located on the edge of the cliff. The aims of the study are: (a) to detect and characterize rockfalls during the monitoring period through a comparison of sequential TLS datasets; (b) to establish a cliff retreat rate. Moreover, a metre scale crack was detected parallel to the rock face (Fig. 1c). This crack constitutes the detachment area of a probable rock slab. As a consequence, the following aim was added to the previous list: (c) to determine the rate of crack opening during the TLS monitoring period.

\subsection{Study area}

The village of Castellfollit de la Roca is located at the top of a Quaternary basaltic formation bounded by two scarps (see Fig. 1a). The Rock face is currently one of the main geomorphological highlights of the Natural Park of the Garrotxa Volcanic Field (GVF). This basaltic elevation is located between two rivers: river Fluvià towards the north and river Turonell towards the south. The basaltic formation is made up of two lava flows (Table 1 and Fig. 1c): the upper lava flow (units A, B, C, and D, Table 1) and lower lava flow (units E, F, and G). Dating these flows using the K-Ar method yielded ages of $192000 \pm 25000$ and $217000 \pm 35000$ years BP, respectively (Donville, 1973; ICC et al., 2007). These units are linked by an irregular deposit formed by pyroclasts and a paleosoil (Pallí and Trilla, 1976; Mallarach and Riera 1981). Table 1 gives a description of the different layers from the viewpoints of geology and engineering geology (modified form Pallí and Trilla, 1976; Mallarach and Riera, 1981; Martí et al., 2000; Mascort et al., 2004; ICC et al., 2007).

\subsection{Historical inventory of rockfalls}

Table 2 shows the historical record in the 30 years prior to the monitoring period: 1976-2006. According to the historical record and monitoring campaigns, mass movements in the study area can be classified as follows:

1. Detachment of single columns (Fig. 2a). The magnitude of this type of event is characterized by volumes below $1.5 \mathrm{~m}^{3}$. As discussed below, our results show a frequency higher than that in the historical record. 
Table 1. Main geological and geomechanical characteristics of the stratigraphic sequence.

\begin{tabular}{|c|c|c|c|c|}
\hline \multicolumn{2}{|c|}{ Lithological units } & \multirow{2}{*}{$\begin{array}{l}\text { Thickness } \\
8 \sim 10 \mathrm{~m}\end{array}$} & \multirow{2}{*}{$\begin{array}{l}\text { Geological description }^{(1)} \\
\text { Basalts. Massive structure. }\end{array}$} & \multirow{2}{*}{$\begin{array}{l}\text { Geomechanical description }{ }^{(2)} \\
\text { Partially weathered and transformed into soil } \\
\text { in the upper part (Ros et al., 1996). A weakening } \\
\text { of the geomechanical properties and an increase } \\
\text { in porosity is to be expected. }\end{array}$} \\
\hline (A) & $\underset{\substack{0 \\
0}}{3}$ & & & \\
\hline (B) & 㐫 & $8 \sim 10 \mathrm{~m}$ & $\begin{array}{l}\text { Basalts. Columnar jointing: } \\
\text { hexagonal pattern. }\end{array}$ & $\begin{array}{l}\text { Discontinuities result from contraction upon } \\
\text { cooling of the lava flow, giving rise to single }\end{array}$ \\
\hline (C) & 5 & $5 \mathrm{~m}$ & Basalts. Wavy prismatic structure. & columns. These discontinuities control \\
\hline (D) & & $5 \mathrm{~m}$ & $\begin{array}{l}\text { Basalts. Columnar jointing: } \\
\text { hexagonal pattern (same as unit B). }\end{array}$ & $\begin{array}{l}\text { the stability of the blocks. Overhanging parts } \\
\text { may affect the local stability of the rock face. }\end{array}$ \\
\hline$(\mathrm{P})$ & $\begin{array}{l}=\overline{0} \\
0 \\
\vdots \\
\frac{0}{\pi} \\
0\end{array}$ & $0.5 \sim 1.5 \mathrm{~m}$ & $\begin{array}{l}\text { Irregular layer of clays and pyroclasts } \\
\text { in the lower part. The upper part contains } \\
\text { a paleosoil and unconsolidated sediments. }\end{array}$ & $\begin{array}{l}\text { Weakness unit (low mechanical properties). } \\
\text { Pyroclasts are not cemented together. } \\
\text { Furthermore, the paleosoil in the upper } \\
\text { part is unconsolidated. In this layer, } \\
\text { porosity is higher than in other layers. }\end{array}$ \\
\hline (E) & 苍 & $3 \sim 4 \mathrm{~m}$ & $\begin{array}{l}\text { Basalts. Wavy prismatic structure. } \\
\text { In some areas also with } \\
\text { a radial structure. }\end{array}$ & Same as B, C and D units. \\
\hline$(\mathrm{F})$ & 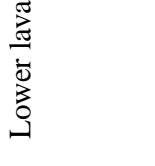 & & Basalts. Lenticular structure. & $\begin{array}{l}\text { High weathering. Discontinuities } \\
\text { control the stability of the blocks. } \\
\text { Overhanging parts may affect the local } \\
\text { stability of the rock face. }\end{array}$ \\
\hline (G) & & $1.5 \mathrm{~m}$ & Basalts. Prismatic layer of short columns. & \\
\hline (H) & 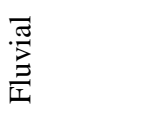 & - & $\begin{array}{l}\text { Quaternary fluvial deposits } \\
\text { prior to lava flows. }\end{array}$ & $\begin{array}{l}\text { Weakness unit } \\
\text { (low mechanical properties). } \\
\text { The erosion of the river may }\end{array}$ \\
\hline (I) & Bedrock & - & Bedrock formed by Eocene sandstone. & $\begin{array}{l}\text { affect global stability because } \\
\text { of undermining phenomena. }\end{array}$ \\
\hline
\end{tabular}

(1) Composition, texture, structure, etc. (2) Mechanical behaviour, porosity, weathering, etc. Vegetation is scattered at all the lithological units and some cracks are filled with clay. Crack opening due to vegetation could be a conditioning factor. Rainfall and pos./neg. variations of temperature are relatively frequent in the study area. As a result, crack opening by gelifraction seems to be a relatively common process.

2. Detachment of a group of columns with a magnitude of 1.5 to $150 \mathrm{~m}^{3}$ (Fig. 2b). This type of failure may involve dozens of columns and may affect different units. The historical record shows 2 events in the last 30 years.

3. Rock slab failures with magnitudes higher than $150 \mathrm{~m}^{3}$ (Fig. 2c). Two slab failures occurred in the last 30 years.

Rockfall events in the study area are poorly documented: there are few data on back analysis of prior events (Mallarach and Mirabell, 1976; Pallí and Trilla, 1976; Ros et al., 1996; Culebras, 2002), magnitude-frequency relationships, conditioning and triggering factors as well as susceptibility assessment (Asensio et al., 2010). Population surveys were conducted to confirm the low frequency of great magnitude rockfalls during the last 50 years. The combination of the historical record (Table 2) and the population surveys is referred to as a long-term approach below.

\subsection{Conditioning and triggering factors}

The role of conditioning factors such as joint pattern, lithology and morphology of the cliff is discussed as follows: (a) the pre-existing columnar joint pattern played a key role in the geometry of the detached blocks. Evidence for this was provided by the rockfalls detected regardless of their size. The influence of the meso-scale structure, i.e. columnar pattern, in the macro-scale morphology of the rock face was also observed: the mean orientation of the rock face corresponds to the mean orientation of the facets of the basaltic columns; (b) the different layout and composition of each of the lithological units described in Table 1 also played an important part in the evolution of the rock face. Two of the levels described in Table 1 were identified as weak levels: pyroclastic level and fluvial deposits. The erosion and/or weathering of these levels create an overhang in the upper levels, affecting their stability, as in the case of 
Table 2. Historical record of rockfalls in the 30 years prior to our study. Modified from Asensio et al. (2010).

\begin{tabular}{|c|c|c|c|c|c|}
\hline $\begin{array}{r}\text { Date of } \\
\text { the rockfall }\end{array}$ & $\begin{array}{l}\text { Location } \\
\text { (souce area) }\end{array}$ & Volume* & Damage & Triggering & References \\
\hline Feb 1976 & $\begin{array}{l}\text { Area of concavity } \\
\text { of the North face, } \\
\text { lower part. }\end{array}$ & $960 \mathrm{~m}^{3}$ & $\begin{array}{l}\text { Any damage. } \\
\text { Undercutting of } \\
\text { the toe of the slope. }\end{array}$ & Continuous rainfall. & $\begin{array}{l}\text { Palau (1976); } \\
\text { Mallarach and } \\
\text { Mirabell (1976) }\end{array}$ \\
\hline Sep 1976 & $\begin{array}{l}\text { Area of concavity } \\
\text { of the North face, } \\
\text { central and upper } \\
\text { part of the rock face. }\end{array}$ & $1500 \mathrm{~m}^{3}$ & $\begin{array}{l}\text { Structural damage to } \\
\text { the porch of a house. }\end{array}$ & $\begin{array}{l}\text { Area destabi- } \\
\text { lized by } \\
\text { the previous } \\
\text { rockfall. }\end{array}$ & $\begin{array}{l}\text { Pallí and } \\
\text { Trilla (1976); } \\
\text { Mallarach and } \\
\text { Mirabell (1976) }\end{array}$ \\
\hline 1977 & Unknown. & $5 \mathrm{~m}^{3}$ & No severe damage. & Unknown. & $\begin{array}{l}\text { Mallarach and } \\
\text { Mirabell (1976) }\end{array}$ \\
\hline Nov 1995 & $\begin{array}{l}\text { Area of concavity } \\
\text { of the North face, } \\
\text { upper part. }\end{array}$ & $50 \mathrm{~m}^{3}$ & $\begin{array}{l}\text { Structural damage to } \\
\text { the porch of a house. }\end{array}$ & Heavy rainfall. & Ros et al. (1996) \\
\hline Mar 2001 & $\begin{array}{l}\text { Single column failure } \\
\text { in the central part of } \\
\text { the North face. }\end{array}$ & $1 \mathrm{~m}^{3}$ & No damage. & Unknown. & Culebras (2002) \\
\hline Feb 2005 & $\begin{array}{l}\text { SE part of } \\
\text { the rock face. }\end{array}$ & $1 \mathrm{~m}^{3}$ & No damage. & Heavy rainfall. & $\begin{array}{l}\text { Population survey } \\
\text { conducted by } \\
\text { RISKNAT } \\
\text { research group. }\end{array}$ \\
\hline Jan/Feb 2006 & $\begin{array}{l}2 \text { single columns } \\
\text { in the SE part of } \\
\text { the rock face. }\end{array}$ & $\begin{array}{c}2-3 \mathrm{~m}^{3} \\
\left(1-1.5 \mathrm{~m}^{3} \text { each }\right)\end{array}$ & No damage. & Heavy rainfall. & \\
\hline
\end{tabular}

* The volumes indicated in this table were roughly estimated from scar dimensions by the aforementioned authors.
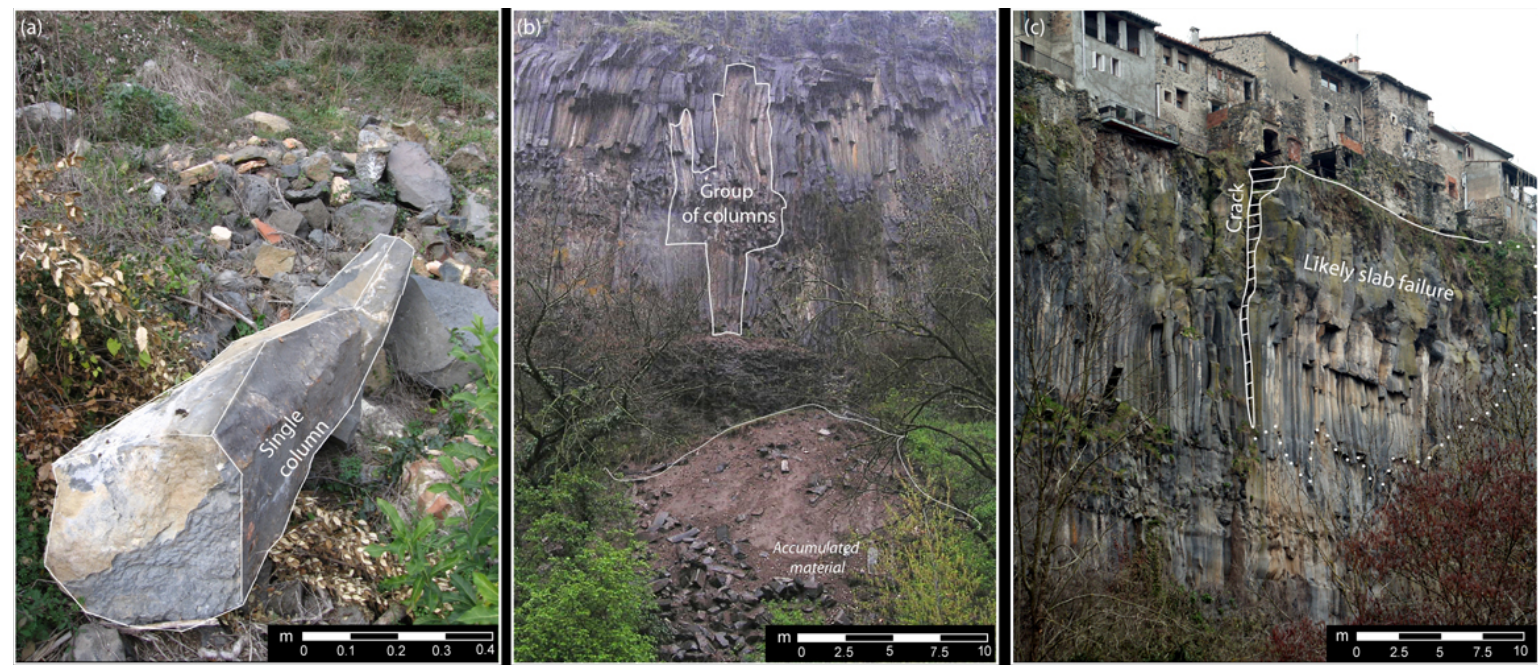

Fig. 2. Type of rockfall according to its volume: (a) detachment of single columns (volume below $1.5 \mathrm{~m}^{3}$ ); (b) detachment of a group of columns (volume from 1.5 to $150 \mathrm{~m}^{3}$ ); (c) likely slab failure (volume higher than $150 \mathrm{~m}^{3}$ ). The picture in Fig. 2b was taken by Llorenç Planagumà. 
the interconnected rockfalls that occurred in February and September 1976 (Table 2). The former rockfall was preceded by a great magnitude event in the lower part of the slope; (c) the morphology of the cliff may affect the local stability of the rock face, e.g. the protruding parts of the slope are likely to collapse.

Regarding triggering factors: (a) the role of precipitation in the rockfalls in the last 30 years was observed by earlier works (Ros et al., 1996; Pallí and Trilla, 1976). Although no direct relationships between climatic variables and rockfall occurrence are discussed in our research, a crack opening due to an ice wedge could be a relatively common process; (b) another triggering factor may be the erosion of the scree deposits and/or of the lower part of the rock face in extraordinary floods (i.e. 1 in 100 years). The maximum curvature of the rock face corresponds to the meander, i.e. the concave part of the river (Fig. 1), where there is more fluvial erosion. This hypothesis may be supported by the fact that the two main mass movements of the historical record (Table 2) took place in this area; (c) finally, the study area is located in a moderate seismic area. Despite its low recurrence, seismicity could also be regarded as a triggering factor, e.g., a destructive earthquake (intensity=IX) with the epicentre located $15 \mathrm{~km}$ away, caused 85 fatalities at the village of Castellfollit de la Roca occurred on 2 February 1428 (Olivera et al., 2006).

\section{Materials and methods}

\subsection{Terrestrial Laser Scanner}

The remote sensing tool employed in this study is a TLS. This instrument is also known as a Ground based LIDAR (Light Detection and Ranging system). We used an ILRIS-3D model (Intelligent Laser Ranging and Imaging System), from the Optech ${ }^{\text {TM }}$ 2004-2006 series. Although this is a well- known technique (see some examples of application in Abellán et al., 2006; Oppikofer et al., 2008; Pesci et al., 2009, etc.), its basic principles are discussed as follows. The instrument mainly consists of a transmitter/receiver of infrared laser pulses and a scanning device (internal system of rotating mirrors). The laser beam is directly reflected by the land surface, obviating the need for intermediate prism reflectors. TLS shows a relatively very high data acquisition speed (up to 10000 points $\mathrm{s}^{-1}$ ) compared with conventional surveying methods (e.g. total stations); more specifically, the ILRIS-3-D model is able to acquire up to 2500 points s $^{-1}$. Range measurement $(\rho)$ can be undertaken using first or last pulse of the return signal; the last pulse is the optimal choice to obtain the return signal of the rock face (in place of vegetation). The distance to an object is calculated using the Time-Of-Flight (TOF) of the laser pulse (Eq. 1):

$\rho=c \cdot(\mathrm{TOF} / 2) \quad[$ Petrie and Toth, 2008]

where $c=$ speed of light.
Spatial resolution is a main function of the point spacing and spot dimension (Lichti and Jamtsho, 2006). The spot dimension increases its value with the distance, through a well know laser beam divergence process (Eq. 2). The greater the spot dimension, the lower the accuracy is.

$S_{\mathrm{D}}=\rho \cdot \tan \alpha+a \quad[$ Petrie and Toth, 2008]

where $\alpha=$ angle of divergence $\left(0.00974^{\circ}\right.$ for ILRIS-3-D); $a=$ initial beam size $(1.2 \mathrm{~cm}$ for ILRIS-3-D); equation in any consistent units of $S_{\mathrm{D}}$ and $\rho$.

The origin of the Cartesian Coordinate System $\left(P_{0}=0,0\right.$, 0 ) is set at the centre of the TLS instrument. Coordinates of each point are acquired in a polar system ( $\rho$ : range; $\vartheta$ : horizontal angle; $\varphi$ :vertical angle). The binary file provided by TLS was transformed into a Cartesian system (x, y, z) using Parser v 4.3.5.4 from Optech ${ }^{\mathrm{TM}}$. As a result, a Parametric Image Format (PIF) file was obtained.

In addition to the 3-D coordinates, the device is able to acquire the value of intensity $(I)$ of instantaneous reflectance of the land surface for an area equal to the spot dimension. This parameter is defined as the amount of reflected signals with respect to the emitted one. It primarily depends on the range, angle of incidence, moisture, surface geometry and object material. Its value is usually normalized on a $0-255$ scale.

The accuracy of the measurement is a main function of the range, reflectivity of the material (Voegtle et al., 2008), complexity of the scanned surface (Abellán et al., 2009) and angle of incidence (Lichti, 2007). Finally, since the operating wavelength of the TLS Ilris 3-D (1535-nm wavelength) is very close to water absorption bands in the atmosphere, data acquisition during rainy or foggy days may be inaccurate. We tested our device at different geological sites and obtained a maximum range of around $600 \mathrm{~m}$ for dry surfaces (e.g. Abellán et al., 2006, 2010; Vilajosana et al., 2008). The technical characteristics supplied by the manufacturer show high point accuracy $(\sigma \sim 0.7 \mathrm{~cm})$ at $100 \mathrm{~m}$ (Optech, 2009). This parameter, which is estimated by comparing two point clouds acquired consecutively, was calculated from 1.5 to $1.7 \mathrm{~cm}$ (see Riera, 2008). This discrepancy may be explained by a lower reflectivity of the rock face, longer range and higher angles of incidence than those tested by the manufacturer. Finally, a thorough planning of the scanning campaign prior to fieldwork is highly recommended: data acquisition may suffer from occlusion and bias problems when the laser beam is parallel to the orientation of the geological surface (e.g. Lichti, 2007; Sturzenegger and Stead, 2009; Lato et al., 2010).

\subsection{Data acquisition}

The first dataset (referred to as reference point cloud, $R_{0}$ below) was acquired in March 2006. The datasets were acquired from five stations (portion of the scanned face, perspective): (a) Station A (north face, frontal); (b) Station B 

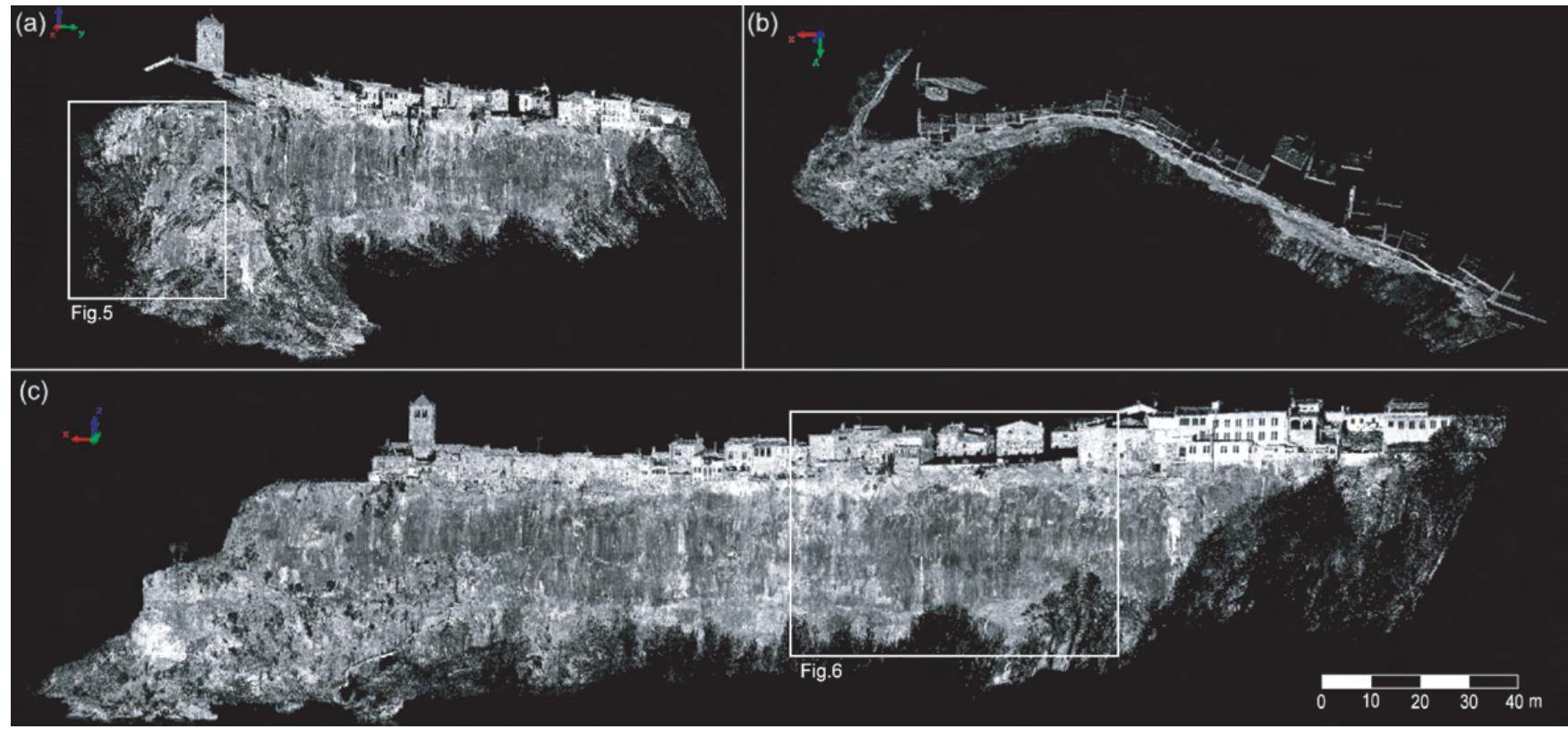

Fig. 3. Images of the aligned TLS datasets: (a) left view: "-X axis"; (b) zenithal view: "+Z axis"; (c) frontal view: "-Y axis". The position of the Figs. 5 and 6 are indicated in Fig. 3a and c, respectively.

(north-east face, oblique); (c) Station C (east face, oblique); (d) Station D (south-east face, frontal) and (e) Station E (north-west, oblique). From these sites, occluded areas were minimized, allowing for the alignment and merging in a single file, creating a final 3-D model (Fig. 3). Since TLS ILRIS-3-D is constrained by a $40 \times 40^{\circ}$ field-of view, seven point clouds were necessary to cover the whole rock face. The mean point spacing of the acquired datasets ranged from 4.5 to $5.5 \mathrm{~cm}$. Each point of the $R_{0}$ was defined as a node for a Triangle Irregular Network (TIN) surface (*.pif file), using a projection plane parallel to the cliff. This surface will be referred to as the surface of reference $\left(S_{0}\right)$ below. Data acquisition was repeated 94, 186, 260, 368, 382, 443, 561, 662 days after $R_{0}$ (periods i, ii, iii, iv, v, vi, vii and viii, respectively). Each of these TLS datasets is referred to as data point cloud $\left(D_{1}, D_{2}, D_{3} \ldots D_{n}\right)$ below.

\subsection{Comparison of sequential TLS datasets}

3-D temporal variations of the terrain were detected by comparing sequential datasets in accordance with the methodology described in Rosser et al. (2005b) and Lim et al. (2006). A brief description is as follows: (a) acquisition of $R_{0}$ (see previous section); (b) construction of the $S_{0}$; (c) acquisition of $D_{1}, D_{2} \ldots D_{n}$; (d) alignment of these datasets with $S_{0}$; (e) comparison between $S_{0}$ and successive $D_{i}$ and (f) calculation of the differences for each period of comparison.

PolyWorks ${ }^{\circledR}$ v9.0 (InnovMetric) was the main software used for the visualization, alignment and comparison of the point clouds. The roto-translation parameters of the alignment matrix (step d) were obtained in three stages: (a) a preliminary registration was performed by a visual identification of homologous points; (b) the alignment was subsequently optimized using an Iterative Closest Points (ICP) procedure (Chen and Medioni, 1992). Using this algorithm, the differences between points were progressively reduced by a minimization of a mean square cost function; and (c) the final improvement was obtained by progressively reducing the "search distance" parameter up to a few centimetres. As a consequence, the meter scale changes (e.g. rockfall) that occurred in the different intervals did not affect the global alignment, alignment error being negligible. Apart from the recorded metre scale rockfalls, the surface of the rock face remained practically unchanged during the scan comparison. The exact date of each event is an unknown factor because of non-continuous data acquisition and the absence of eyewitnesses.

The single point distances between the $S_{0}$ and the subsequent $D_{i}$ were computed in the IMInspect module of PolyWorks ${ }^{\circledR}$ v.9 software using a conventional methodology (data vs. reference comparison). Comparisons based on "Shortest distance" methodologies reduced the values of the real changes that took place, i.e. rockfalls. Hence, the direction of comparison was defined as the normal vector of the rock face at its central part. The differences $\left(\right.$ Dif $\left._{i}\right)$ were calculated for each point as shown in Eq. (3):

$\operatorname{Dif}_{i}=\operatorname{Distance}\left[S_{i} P_{0}\right]-\operatorname{Distance}\left[S_{0} P_{0}\right]$

Part of the value of Dif $_{i}$ is due to systematic (instrumental and methodological) errors. The other part is due to 
"real changes" in certain parts of the slope, e.g. rockfalls, vegetation growing, etc. With regards to the sign criteria, we use positive values when the time of flight of the laser signal for $D_{i}$ is higher than that of $S_{0}$. As a result, positive values correspond to a lack of material at a given point, i.e. detachment of the material. Likewise, negative values correspond to an increase in material, i.e. scree deposits, or vegetation growth. This negative displacement may also reflect the pre-failure deformation in a part of the slope (i.e. Abellán et al., 2009, 2010). The volume of the main events was calculated using the "surface to a plane" command of the IMInspect module (PolyWorks). In line with Rosser et al. (2005b), rockfalls with a volume under $0.001 \mathrm{~m}^{3}$ were not considered in this study.

\subsection{Assessment of the quality of the rock face modelling}

The influence of angular resolution, i.e. density of points, in the quality of the surface of reference was tested by comparing two point clouds acquired consecutively. Figure 4a shows the percentiles of the error as a function of the density of points. As expected, the lower the density of points, the lower the accuracy of the comparison. The value of the 75th, 90th and 95th percentiles show similar values of the error for a point spacing below $4.7 \mathrm{~cm}$. As a result, no significant improvements are obtained by increasing the density of points. For this reason, the Optimal Point Spacing (OPS) ranges from 4.5 up to $5.5 \mathrm{~cm}$ in the study area.

Figure $4 \mathrm{~b}$ shows the histogram of the model comparison in the same section, using a point spacing of $4.7 \mathrm{~cm}$. This histogram is characterized by a very high kurtosis, i.e. the presence of infrequent extreme deviations. Assuming a normal distribution, the dispersion of the $68 \%$ of the population can be explained by the standard deviation $(1 \sigma)$ parameter. However, in accordance with the ASPRS LiDAR Committee (2004), a normal distribution of error cannot be assumed where the population does not fit a normal/Gaussian distribution, as in the case of Fig. $4 \mathrm{~b}$. Alternatively, the variance of the population was assessed by means of the percentiles of the error. Two different populations can be found in this histogram: (a) instrumental error, corresponding to the error of $90 \%$ of the population, i.e. between -3.04 and $+2.99 \mathrm{~cm}$ (5th and 95 th percentile, respectively); (b) outliers: data artefacts that were mainly found along the boundaries of the occluded parts of the slope with respect to the TLS line-of-sight (LOS). These data artefacts were quantified by the 99th percentile, i.e. the error of $2 \%$ of the population was higher than $8.39 \mathrm{~cm}$. The morphology of the rock face plays an important role in the magnitude and extent of these outliers: the greater the complexity of the scanned surface, the higher the variance of the measurement. In the study area, the outliers tended to concentrate along the borders of the basaltic columns.

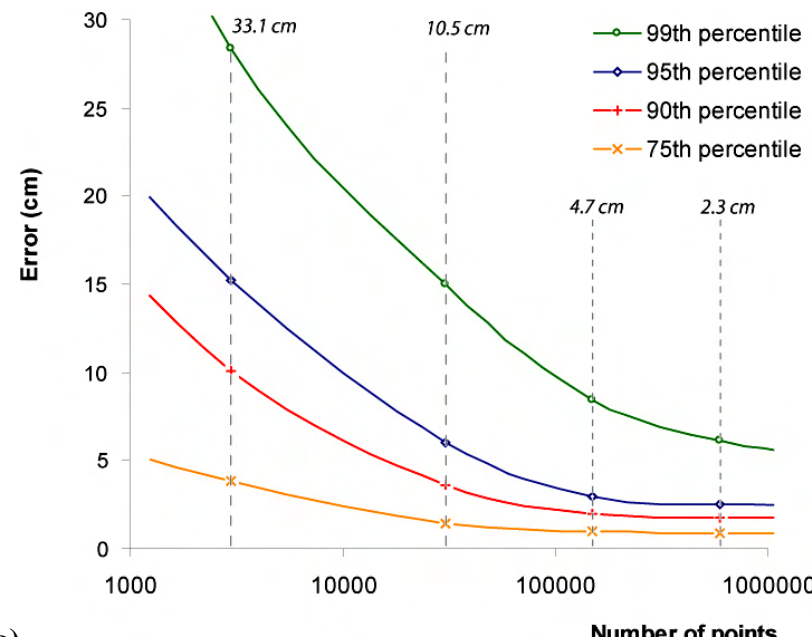

(a)

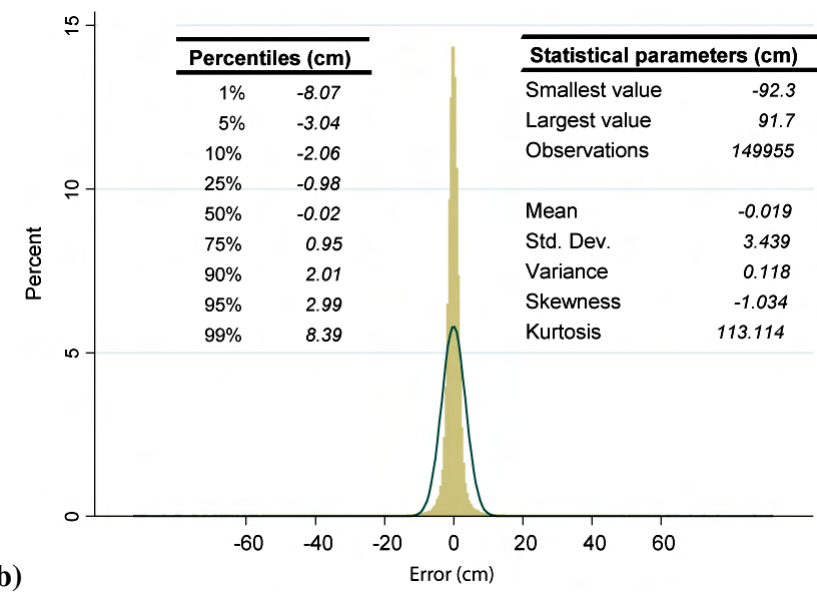

Fig. 4. Assessment of the quality of rock face modelling. (a) Variance of the population assessed for different densities of points through the percentiles of the error of the model comparison; (b) probability distribution of the error of the model comparison using a mean point spacing of $4.7 \mathrm{~cm}$. The histogram is characterized by considerable kurtosis and a poor resemblance to a fitted Gaussian distribution (blue line). See text for a detailed explanation.

The most accurate results were obtained from Stations A and D, respectively. Riera (2008) reported the accuracy of the TLS point cloud for different geological layers and sections of the rock face, finding out that the accuracy at rock outcrops reached higher values than that obtained in vegetated areas. Consequently, accuracy was improved by the deletion of unexpected points (e.g. wires, birds, etc.) together with manual removal of trees in the lower part of the cliff (see Fig. 1d) and small bushes. In addition, it can also be improved by filtering the areas similarly oriented to the LOS (Lichti, 2007). 


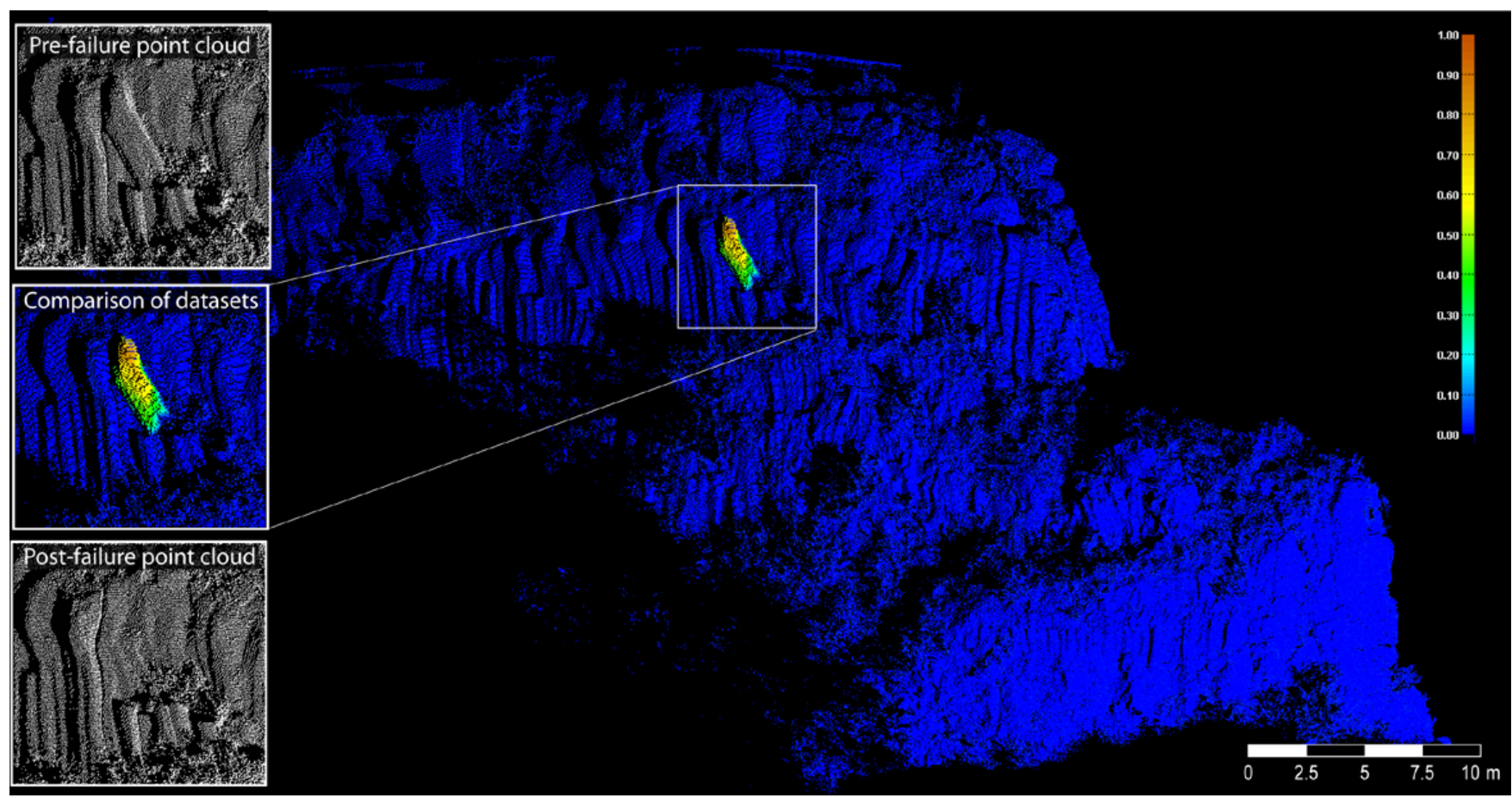

Fig. 5. Comparison of the sequential TLS datasets. Each point of the 3 -D point cloud is colour-coded in accordance with the changes recorded during the period of comparison (September vs. December 2006). The failure of a single basaltic column and small changes in vegetation are visible. Pre and post failure stages are visible on the left.

\section{Results}

\subsection{Detachment of single columns}

The detachment of single columns is the mass movement of highest frequency and lowest magnitude in the study area. The detachment of six basaltic columns was recorded in the 22-month monitoring period. The magnitude of each of these rockfalls is below $1.5 \mathrm{~m}^{3}$. The geometry of these rockfalls is controlled by the columnar joint pattern. Figure 5 shows a sequential comparison of September and December 2006 TLS datasets in the southern part of the rock face. A single column detachment is clearly visible in the middle of the figure.

\subsection{Detachment of a group of columns}

A failure that affected a group of columns in the central part of the rock face (Fig. 6a) was recorded in our research. This event can be described as a combination of two interconnected detachments:

1. The April 2007 rockfall (event i, Fig. 6b) is the event of the highest magnitude during the monitoring period. This figure shows a comparison of the sequential datasets corresponding to 30 May 2007 and 13 April 2007. An irregular failure with maximum dimensions of $15-\mathrm{m}$ height, $6 \mathrm{~m}$ width and $1.5 \mathrm{~m}$ thickness is observed in the middle of the figure. Tens of basaltic columns belonging to levels B, C and D (Fig. 1c) were mobilized. The rockfall volume $\left(50 \mathrm{~m}^{3}\right)$ was calculated by volume differences between pre and post failure surfaces. The morphology of the cliff prior to the rockfall revealed a protruding block partly supported by the pyroclastic $(P)$ level. The geometry of the surface of detachment is controlled by the columnar joint pattern. A period of continuous rainfall $(100 \mathrm{~mm}$ in 6 days) may have triggered this rockfall.

2. A second event (event ii, Fig. 6c) took place in the same area as the April 2007 rockfall, six to nine months afterwards (October 2009-January 2010). This event consisted of a few blocks from unit $\mathrm{C}\left(1.5 \mathrm{~m}^{3}\right)$ in addition to a single column from unit $\mathrm{B}\left(1.5 \mathrm{~m}^{3}\right)$. As in the case of the interconnected rockfalls of February and September 1976, the origin of this event was interpreted as a gravitational readjustment of the scarp after the event of April 2007. As a result of these rockfalls, the upper part of the slope lost part of its basal support. Hence, the occurrence of a future event in this area is likely. 


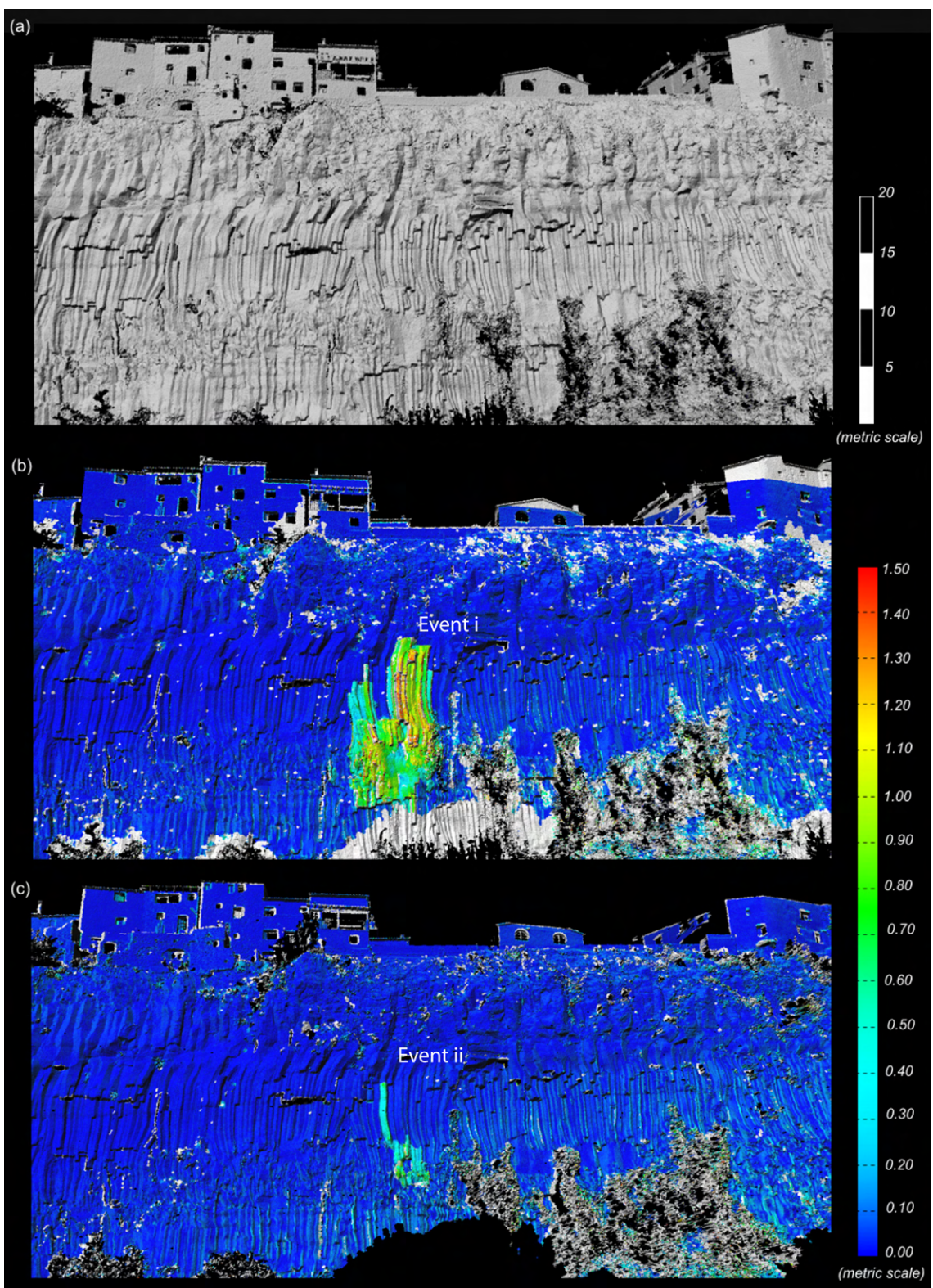

Fig. 6. (a) TIN surface of a part of the rock face where events i and ii took place; (b) comparison of the March and April 2007 datasets; (c) comparison of the October 2007 and January 2008 datasets. Each point is colour-coded according to the changes during the period of comparison. Colour scale indicates positive differences along the $\mathrm{Y}$ direction, e.g. rockfalls. Note that event ii is in the same area as event i.

\subsection{Slab failures}

No rock slab failures were recorded in the monitoring period. However, the detection of a metre scale crack during fieldwork (Fig. 2c) provided evidence of the occurrence of an ongoing rock slab failure with an estimated volume exceeding $500 \mathrm{~m}^{3}$. This section of the rock face was monitored by TLS given the high vulnerability of the houses located above the slab and on the edge of the cliff. The results showed no significant pre-failure deformation in this area during the 22-month monitoring period. This suggests that the maximum value of the displacement is lower than the instrumental error (95th percentile) by the time span of the monitoring period, i.e. lower than $1.64 \mathrm{~cm} \mathrm{year}^{-1}(3 \mathrm{~cm}$ in 22 months). Although this hypothetical displacement seems currently stationary, its future reactivation cannot be ruled out. 


\section{Discussion}

\subsection{Critical review of the results}

The use of TLS enabled us to better understand rockfall phenomena of the rock face at Castellfollit de la Roca. While established surveying methods (i.e. a total station, extensometers, etc.) allow for the acquisition of millimetrelevel accuracy of a small number of control points, TLS datasets consist in millions of points with a centimetrelevel accuracy. This complete coverage of the surface has allowed for the morphological characterization of the rock face, the location and volume of rockfalls (e.g. Lim et al., 2006; Rosser et al., 2007) and the monitoring of a likely rock slab failure. Some limitations were also encountered in our research: (a) range measurements are erroneous in the presence of water seepage when using TLS ILRIS3-D. These measurements were not considered; (b) the instrumental and methodological errors could be higher than the real displacement of the probable slab failure (see previous section). The use of more accurate techniques, e.g. extensometers, total stations or ground based radar, may overcome this limitation; (c) the exact date of each rockfall event is unknown because of discrete TLS measurements; a continuous, real-time TLS record would have enabled us to better understand the triggering factors, e.g. climatic variables; (d) a longer monitoring period is needed to obtain a more accurate record of large-scale events;

The results obtained by the long-term and short-term (i.e. monitoring by TLS) approaches are discussed below:

Table 3a shows rockfall activity for the different types of mass movements using a long-term approach (Sect. 1.2). As regards the number of rockfalls, a similar number of small, medium and large events were recorded, suggesting that the frequency is not dependent on the magnitude, which appears to be inconsistent with the inverse power law obtained in many studies (e.g. Hungr et al., 1999; Malamud et al., 2004; Lim et al., 2009). Furthermore, a period of recurrence of 17 years for the detachment of a single column does not tally with our TLS results, indicating that there is clearly insufficient temporal extent and spatial sensitivity within the historical record. Table $3 \mathrm{~b}$ shows rockfall activity for the different types of mass movements based on the sequential comparison of TLS datasets in the monitoring period. A scale dependency of the number of events was obtained, which is consistent with previous studies. However, this approach suffers from an absence of time span, especially for large scale rockfalls (higher than $150 \mathrm{~m}^{3}$ ).

Historical and TLS approaches have suffered from systematic errors in the estimation of rockfall frequency. The historical approach suffered from a bias in the recording of the phenomena: only rockfalls with a volume above a certain value are normally recorded and/or detected by witnesses (e.g. Hungr et al., 1999). By contrast, the results of the TLS campaign were temporally biased: the low frequency of medium and large scale rockfalls demanded a longer period of study. As pointed out by Rosser et al. (2005a), comparison between the high resolution contemporary monitoring and the long term historic record may help to understand rockfall rates and processes. Although the limitations discussed above exist(magnitude biases), an attempt to combine both approaches is discussed in the next section.

\subsection{Combination of long-term and short-term approaches}

An attempt to quantify the recurrence and volume of rockfalls during the last 50 years is discussed as follows (see Table 4): (a) the recurrence of the small scale rockfalls was assessed using a short-term approach, i.e. the TLS campaign; (b) the recurrence of medium scale rockfalls was estimated as a combination of long-term (i.e. historical record)/short-term approaches. Its value ranged from 2 to 11 years: on the one hand, one event was recorded during the monitoring period, i.e. a period of recurrence of 1.8 years; on the other hand, three events were recorded in 1976-2008, i.e. a period of recurrence of 10.7 years; (c) the recurrence of the large scale rockfalls was assessed based on the long-term approach. Two events were recorded in the last 50 years, i.e. a recurrence of 25 years. An error margin should be considered for the following reasons: (a) rockfall is not a homogeneous and continuous process; (b) the results are biased in the longterm approach (small scale rockfalls are ignored); and (c) the results using the TLS approach are of insufficient temporal extent to represent the full range of failures that are expected to occur (i.e., large scale events are biased).

Even failures are clearly episodic, the mean cliff retreat rate was estimated assuming a detachment of material from 46 to $91.5 \mathrm{~m}^{3}$ year $^{-1}$ (Table 4 ) and an area of the rock face of $\sim 8000 \mathrm{~m}^{2}$.

\subsection{Implications of the results}

There are two vulnerable scenarios in the study area: the lower and the upper parts of the cliff. Which phenomenon represents the most severe threat to the population? Small scale rockfalls account for 87-96\% of these events (Table 4), their effect on the total cliff retreat is much less, only from 4 to $6 \%$. Nevertheless, large-scale rockfalls make up $\sim 1 \%$ of the events, their effect on the cliff retreat is much greater (from 58 to 87\%). No permanent vulnerable elements are located at the base of the cliff: hence, the detachment and propagation of the low magnitude and high frequency rockfalls constitute a reduced risk in this area. In contrast, the houses located on the edge of the cliff are more likely to be damaged by large-scale rockfalls, as in the event of September 1976 (Table 2). Subsequent efforts should be focused on early detection of the most hazardous, i.e. events of great magnitude $\left(>150 \mathrm{~m}^{3}\right)$. 
Table 3. (a) Long-term results based on historical record and population surveys. Time span: 50 years prior to this study. (b) Short-term results based on a sequential comparison of TLS datasets. Time span: 22 months.

(a) Long-term approach

\begin{tabular}{rlccccc}
\hline Magnitude & \multicolumn{2}{l}{ Recorded rockfalls ${ }^{(1)}$} & Estimated recurrence & \multicolumn{2}{l}{ Volume } \\
\hline$<1.5 \mathrm{~m}^{3}$ & 3 & $43 \%$ & $\sim 10 \mathrm{yr}^{(2)}$ & $4.5 \mathrm{~m}^{3(4)}$ & $0.1 \mathrm{~m}^{3} \mathrm{yr}^{-1(5)}$ & $0.3 \%$ \\
$1.5-150 \mathrm{~m}^{3}$ & 2 & $28.5 \%$ & $\sim 15 \mathrm{yr}^{(2)}$ & $55 \mathrm{~m}^{3(4)}$ & $1.8 \mathrm{~m}^{3} \mathrm{yr}^{-1(5)}$ & $3.6 \%$ \\
$>150 \mathrm{~m}^{3}$ & 2 & $28.5 \%$ & $\sim 25 \mathrm{yr}^{(3)}$ & $2460 \mathrm{~m}^{3(4)}$ & $49 \mathrm{~m}^{3} \mathrm{yr}^{-1(6)}$ & $96.1 \%$ \\
Total & 7 & $100 \%$ & - & $2520 \mathrm{~m}^{3}$ & $50 \mathrm{~m}^{3} \mathrm{yr}^{-1}$ & $100 \%$ \\
\hline
\end{tabular}

(b) Short-term approach

\begin{tabular}{rlccccc}
\hline Magnitude & \multicolumn{2}{l}{ Recorded rockfalls $^{(7)}$} & Estimated recurrence & & \multicolumn{2}{c}{ Volume } \\
\hline$<1.5 \mathrm{~m}^{3}$ & 6 & $86 \%$ & $\sim 0.3 \mathrm{yr}$ & $6 \mathrm{~m}^{3(9)}$ & $3.3 \mathrm{~m}^{3} \mathrm{yr}^{-1(10)}$ & $11 \%$ \\
$1.5-150 \mathrm{~m}^{3}$ & 1 & $14 \%$ & $\sim 1.8 \mathrm{yr}$ & $50 \mathrm{~m}^{3(9)}$ & $28 \mathrm{~m}^{3} \mathrm{yr}^{-1(10)}$ & $89 \%$ \\
$>150 \mathrm{~m}^{3}$ & 0 & $0 \%$ & - & $0 \mathrm{~m}^{3(3)}$ & $0 \mathrm{~m}^{3} \mathrm{yr}^{-1(10)}$ & $0 \%$ \\
Total & 7 & $100 \%$ & - & $56 \mathrm{~m}^{3(3)}$ & $31 \mathrm{~m}^{3} \mathrm{yr}^{-1(10)}$ & $100 \%$ \\
\hline
\end{tabular}

(1) Number of rockfalls from the historical record (see Table 2). (2) Time span of 30 years (historical record, Table 2) divided by the number of rockfalls. (3) Time span of 50 years (historical record and surveys to population, see Sect. 1.2) divided by the number of rockfalls. ${ }^{(4)}$ The volume was estimated using the historical record (see Table 2 ). ${ }^{(5)}$ Calculated as the total volume divided by a time span of 30 years. ${ }^{(6)}$ Calculated as the total volume divided by a time span of 50 years. ${ }^{(7)}$ Rockfalls recorded using a sequential comparison of TLS datasets. ${ }^{(8)}$ Time span (1.8 years) divided by the number of rockfalls. ${ }^{(9)}$ Volume was calculated comparing TLS datasets. ${ }^{(10)}$ Calculated as the total volume divided by a time span of 1.8 years.

Table 4. Combination of short and long-term approaches: TLS monitoring campaign, historical record and population surveys. This table attempts to quantify the recurrence and volume of the rockfalls in the last 50 years. The calculation of a "probability of occurrence" is beyond the scope of this research.

\begin{tabular}{|c|c|c|c|c|c|c|}
\hline \multirow{2}{*}{$\begin{array}{r}\text { Magnitude } \\
<1.5 \mathrm{~m}^{3}\end{array}$} & \multirow{2}{*}{$\begin{array}{l}\text { Estimated recurrence } \\
0.25-0.35 \mathrm{yr}^{(1)}\end{array}$} & \multicolumn{2}{|c|}{$\begin{array}{l}\text { Estimated num. of rockfalls } \\
\left(_{(50 \text { years })^{(4)}}\right.\end{array}$} & \multicolumn{3}{|c|}{$\begin{array}{l}\text { Estimated volume } \\
\text { (50 years })\end{array}$} \\
\hline & & $140-200$ & $87-96 \%$ & $135-200 \mathrm{~m}^{3}(5)$ & $2.5-4 \mathrm{~m}^{3} \mathrm{yr}^{-1(8)}$ & $4-6 \%$ \\
\hline $1.5-150 \mathrm{~m}^{3}$ & $2-11 \mathrm{yr}^{(2)}$ & $5-25$ & $3.3-11 \%$ & $175-1375 \mathrm{~m}^{3}(6)$ & $3.5-27.5 \mathrm{~m}^{3} \mathrm{yr}^{-1(8)}$ & $5-40 \%$ \\
\hline$>150 \mathrm{~m}^{3}$ & $20-30 \mathrm{yr}^{(3)}$ & $1-3$ & $0.7-1.3 \%$ & $2000-3000 \mathrm{~m}^{3(7)}$ & $40-60 \mathrm{~m}^{3} \mathrm{yr}^{-1(8)}$ & $58-87 \%$ \\
\hline Total & - & $146-228$ & $100 \%$ & $2300-4575 \mathrm{~m}^{3}$ & $46-91.5 \mathrm{~m}^{3} \mathrm{yr}^{-1}$ & $100 \%$ \\
\hline
\end{tabular}

(1) Assessed based on the results of the TLS monitoring campaign (see Table 3b) assuming an error margin of $\pm 20 \%$. (2) Estimated as a combination of TLS and historical record (see text). (3) Assessed based on the long-term approach (see Table 3a) assuming an error margin of $\pm 20 \%$. ${ }^{(4)}$ Calculated as the recurrence multiplied by a time span of 50 years. (5) Calculated assuming a constant volume of $1 \mathrm{~m}^{3}$. ${ }^{(6)}$ Estimated as a combination of TLS and historical record: the cumulated volume in a time span of 30 years was calculated as $105 \mathrm{~m}^{3}$, i.e. $175 \mathrm{~m}^{3}$ in 50 years. ${ }^{(7)}$ Cumulated volume of the February and September 1976 events (Table 2). ${ }^{(8)}$ Calculated as the total volume divided by a time span of 50 years.

A deformation of a few centimetres prior to the occurrence of the April 2007 event was observed (Abellán et al., 2009). Assuming that the most hazardous types of mass movements in the study area, i.e. medium and large- scale rockfalls, are usually preceded by slow displacements (e.g. Zvelebill and Moser, 2001; Rose and Hungr, 2007; Abellán et al., 2010), a TLS monitoring system could be used for the early detection of rockfalls. Further research may provide a more accurate estimation of the rate of cliff retreat by increasing the TLS monitoring period.

\section{Conclusions}

High resolution and high accuracy TLS datasets have helped us deepen our understanding of rockfall phenomena at Castellfollit de la Roca. Two types of mass movement were detected in the monitoring period: (a) detachment of six basaltic columns, with a magnitude below $1.5 \mathrm{~m}^{3}$ and (b) detachment of a group of columns, with magnitudes of $50 \mathrm{~m}^{3}$. Moreover, the displacements of a likely slab failure in the central part of the cliff were measured, suggesting an apparent stationary stage (displacements lower than $1.64 \mathrm{~cm}$ year $\left.^{-1}\right)$. The long-term and TLS approaches 
suffered from a bias in the recording of the rockfall phenomena. A combination of these approaches allowed us to better estimate (a) the magnitude and frequency of the rockfalls in the study area and (b) the mean annual rate of retreat. This procedure has proven to be a valuable tool for rockfall hazard assessment in urban areas.

\section{Supplementary material related to this article is available online at: http://www.nat-hazards-earth-syst-sci.net/11/829/2011/ nhess-11-829-2011-supplement.zip.}

Acknowledgements. The financial support of the Spanish Ministry of Science and Education (pre-doctoral grant 2004-1852) is gratefully acknowledged. This work was funded by the Natural Park of the Garrotxa Volcanic Field (PNZVG), the Geomodels Institute, Group RISKNAT (SGR2009-520) and following projects: MEC CGL2006-06596 (DALMASA) and TopoIberia CSD20060004/Consolider-Ingenio2010. George von Knorring improved the English draft of the manuscript. The valuable comments of our colleagues Guillem Gisbert and Giorgi Khazaradze are also acknowledged. The picture of Fig. $2 b$ was taken by Llorenç Planagumà. Daily rainfall was provided by the Servei Metereologic de Catalunya (www.meteo.cat). We are very grateful to our colleagues from the PNZVG and IGAR (Univ. Lausanne) for their support during fieldwork campaigns and during the review process of the manuscript, respectively. Finally, we also acknowledge the reviewers (M. Lato and an anonymous reviewer) and the journal editor (A. Günther) which considerably improved the final version of the document.

Edited by: A. Günther

Reviewed by: M. Lato and another anonymous referee

\section{References}

Abellán, A., Vilaplana, J. M., and Martínez, J.: Application of a long-range Terrestrial Laser Scanner to a detailed rockfall study at Vall de Núria (Eastern Pyrenees, Spain), Eng. Geol., 88, 136148, 2006

Abellán, A., Jaboyedoff, M., Oppikofer, T., and Vilaplana, J. M.: Detection of millimetric deformation using a terrestrial laser scanner: experiment and application to a rockfall event, Nat. Hazards Earth Syst. Sci., 9, 365-372, doi:10.5194/nhess-9-3652009, 2009.

Abellán, A., Calvet, J., Vilaplana, J. M., and Blanchard, J.: Detection and spatial prediction of rockfalls by means of terrestrial laser scanner monitoring, Geomorphology, 119(3-4), 162-171, doi:10.1016/j.geomorph.2010.03.016, 2010.

Asensio, E., Vilaplana, J. M., and Abellán, A.: Anàlisi detallada de la susceptibilitat als despreniments a la cinglera de Castellfollit de la Roca, en: Libro de actas de las Jornades de Recerca i Gestio del Patrimoni Natural: La vulcanología al Parc Natural de la Zona Volcánica de la Garrotxa, Olot, 2010 (in Spanish).

ASPRS LiDAR Committee: ASPRS Guidelines Vertical Accuracy Reporting for LiDAR Data, available at:
http://www.asprs.org/society/committees/lidar/Downloads/ Vertical_Accuracy_Reporting_for_Lidar_Data.pdf, 2004.

Bauer, A., Paar, G., and Kaltenböck, A.: Mass movement monitoring using terrestrial laser scanner for rock fall management, Proceedings of the First International Symposium on GeoInformation for Disaster Management, Delft, The Netherlands, 393-406, 2005.

Biasion, A., Bornaz, L., and Rinaudo, F.: Laser Scanning Applications on Disaster Management, in: Geo-information for Disaster Management, edited by: van Oosterom, P., Zlatanova, S., and Fendel, E. M., Springer, Berlin, 19-33, 2005.

Chen, Y. and Medioni, G.: Object Modelling by Registration of Multiple Range Images, Image Vision Comput., 10, 145-155, 1992.

Copons, R. and Vilaplana, J. M.: Rockfall susceptibility zoning at a large scale: From geomorphological inventory to preliminary land use planning, Eng. Geol., 102(3-4), 42-51, 2008

Culebras, J.: Castellfollit de la Roca. Quaderns de la Revista de Girona. Diputació de Girona, 96 pp., 2002 (in Catalan).

Dewez, T., Gebrayel, D., Lhomme, D., and Robin, Y.: Quantifying morphological changes of sandy coasts by photogrammetry and cliff coasts by lasergrammetry, La Houille Blanche, 1, 32-37, doi:10.1051/lhb:2009002, 2009.

Donville, B.: Geologie néogéne et âges des eruptions volcaniques de la Catalogne Orientale, Thèse Univ. Paul Sabatier, Toulousse, 356 pp., 1973 (in French).

Dunning, S. A., Massey, C. R., and Rosser, N. J.: Structural and geomorphological controls on landslides in the Bhutan Himalaya using Terrestrial Laser Scanning, Geomorphology, 103(1), 1729, 2009.

Hungr, O., Evans, S. G., and Hazzard, J.: Magnitude and frequency of rock falls and rock slides along the main transportation corridors of southwestern British Columbia, Can. Geotech. J., 36, 224-238, 1999.

Institut Cartogràfic de Catalunya (ICC), Institut Geològic de Catalunya (IGC), and Parc Natural de la Zona Volcànica de la Garrotxa (PNZVG): Carta vulcanològica de la zona volcànica de la Garrotxa [cartographic material], Scale: 1:25 000, $93 \times 96 \mathrm{~cm}$, edited by: ICC, 2007 (in Spanish).

Jaboyedoff, M., Metzger, R., Oppikofer, T., Couture, R., Derron, M.-H., Locat, J., and Turmel, D.: New insight techniques to analyze rock-slope relief using DEM and 3D-imaging cloud points: COLTOP-3D software, in: Rock mechanics: Meeting Society's Challenges and demands (Vol. 2), Eberhardt, E., Stead, D., and Morrison T., Taylor \& Francis, 61-68, 2007.

Jaboyedoff, M., Oppikofer, T., Abellán, A., Derron, M.-H., Loye, A., Metzger, R., and Pedrazzini, A.: Use of LIDAR in landslide investigations: a review, Nat. Hazards, 1-24, doi:10.1007/s11069-010-9634-2, 2010.

Lato, M. J., Diederichs, M. S., and Hutchinson, D. J.: Bias Correction for View-limited Lidar Scanning of Rock Outcrops for Structural Characterization, Rock Mech. Rock Eng., 43, 615628, 2010.

Lichti, D. D.: Error modelling, calibration and analysis of an AMCW terrestrial laser scanner system, ISPRS J. Photogramm., 61(5), 307-324, 2007.

Lichti, D. D. and Jamtsho, M.: Angular resolution of terrestrial laser scanners, Photogramm. Rec., 21(114), 141-160, 2006.

Lim, M., Petley, D. N., Rosser, N. J., Allison, R. J., Long, A. J., and 
Pybus, D.: Combined digital photogrammetry and time-of-flight laser scanning for monitoring cliff evolution, Photogramm. Rec., 20(1), 109-129, 2006.

Lim, M., Rosser, N. J., Allison, R. J., and Petley, D. N.: Erosional processes in the hard rock coastal cliffs at Staithes, North Yorkshire, Geomorphology, 114(1-2), 12-21, doi:10.1016/j.geomorph.2009.02.011, 2009.

Malamud, B. D., Turcotte, D. L., Guzzetti, F., and Reichenbach, P.: Landslide inventories and their statistical properties. Earth Surf. Proc. Land., 29(6), 687-711, doi:10.1002/esp.1064, 2004.

Mallarach, J. M. and Mirabell, E: Informe Geològic sobre les esllavissades de la tardor de 1976 a la cinglera basàltica de Castellfollit de la Roca, La Garrotxa, unpublished material, 1976 (in Spanish).

Mallarach, J. M. and Riera, M.: Els volcans olotins i el seu paisatge, Serpa, Girona, 62-69 i 192-200, 1981 (in Catalan).

Martí, J., Pujades, A., Ferrés, D., Planagumà, L., and Mallarach, J. M.: El Vulcanisme. Guia de camp de la zona volcànica de la Garrotxa. Guies del Parc Natural de la Zona Volcànica de la Garrotxa, Departament de Medi Ambient de la Generalitat de Catalunya, Barcelona, 106 pp., 2000 (in Catalan).

Mascort, D., Martorell, E., Rovira, A., Montserrat, A., and Pujol, D.: Estudi geologic de la zona de Castellfollit de la Roca, Parc Natural de la Zona Volcánica de la Garrotxa, 30 pp., 2004 (in Catalan).

Monserrat, O. and Crosetto, M.: Deformation measurement using terrestrial laser scanning data and least squares 3D surface matching. ISPRS J. Photogramm., 63(1), 142-154, 2008.

Olivera, C., Redondo, E., Lambert, J., Riera Melis, A., and Roca, A.: Els Terratrèmols dels segles XIV i XV a Catalunya, Generalitat de Catalunya, Institut Cartogràfic de Catalunya, 407 pp., 2006 (in Catalan).

Oppikofer, T., Jaboyedoff, M., and Keusen, H.-R.: Collapse of the eastern Eiger flank in the Swiss Alps, Nat. Geosci., 1(8), 531535,2008

Optech: ILRIS-3D Intelligent Laser Ranging and Imaging System, available at: http://www.optech.ca/i3dprodline-ilris3d.htm (last access: 12 June 2009), 2009.

Palau, A.: Dictamen sobre las causas y remedios de las grietas y desprendimientos en el cingle o acantilado basaltico de Castellfollit de la Roca, Excmo, ayuntamiento de Castellfollit de la Roca, Girona, 35 pp., 1976 (in Spanish).

Pallí, L. and Trilla, J.: Estudio de los desprendimientos en el acantilado o "cingle"de Castellfollit de la Roca, Excma, diputación provincial de Girona, Girona, 37 pp., 1976 (in Spanish).

Pesci, A., Casula, G., Loddo, F., Bianchi, M. G., and Teza, G.: Optech Ilris-3d Terrestrial Laser Scanner: Short User Guide. Technical report, 24 pp., available at: http://www.earth-prints. org/handle/2122/5207, 2009.

Petrie, G. and Toth, C. K.: Introduction to laser ranging, profiling, and scanning, in: Topographic Laser Ranging and Scanning: principles and processing, edited by: Shan, J. and Toth, C. K., CRC Press, Taylor \& Francis, 590 pp., 2008.

Pieraccini, M., Noferini, L., Mecatti, D., Atzeni, C., Teza, G., Galgaro, A., and Zaltron, N.: Integration of radar interferometry and laser scanning for remote monitoring of an urban site built on a sliding slope, IEEE T. Geosci. Remote, 44(9), 2335-2342, 2006.
Prokop, A. and Panholzer, H.: Assessing the capability of terrestrial laser scanning for monitoring slow moving landslides, Nat. Hazards Earth Syst. Sci., 9, 1921-1928, doi:10.5194/nhess-91921-2009, 2009.

Rabatel, A., Deline, P., Jaillet, S., and Ravanel, L.: Rock falls in high-alpine rock walls quantified by terrestrial lidar measurements: A case study in the Mont Blanc area, Geophys. Res. Lett., 35, L10502, doi:10.1029/2008GL033424, 2008.

Riera, E.: Development and analysis of Laser Scanner data, MSc thesis, Technical University of Catalonia, 67 pp., 2008.

Ros, X., Palomar, J., and Gaete, R.: Estudi geotècnic del cingle de Castellfollit de la Roca, Parc Natural de la Zona Volcánica de la Garrotxa (PNZVG), 157 pp., 1996 (in Catalan).

Rose, N. D. and Hungr, O.: Forecasting potential rock slope failure in open pit mines using the inverse-velocity method, International J. Rock Mech. Min., 44(2), 308-320, 2007.

Rosser, N. J., Dunning, S. A., Lim, M., and Petley, D. N.: Terrestrial laser scanning for quantitative rock fall hazard assessment, in: Landslide risk management edited by: Hungr, O., Fell, R., Couture, R., and Eberhardt, E., Balkema, Rotterdam, paper 091, 2005a.

Rosser, N. J., Petley, D. N., Lim, M., Dunning, S. A., and Allison, R. J.: Terrestrial laser scanning for monitoring the process of hard rock coastal cliff erosion, Q. J. Eng. Geol. Hydroge., 38(4), 363-375, 2005b.

Rosser, N. J., Lim, N., Petley, D. N., Dunning, S., and Allison, R. J.: Patterns of precursory rockfall prior to slope failure, J. Geophys. Res., 112, F04014, doi:10.1029/2006JF000642, 2007.

SafeLand deliverable 4.1: Review of Techniques for Landslide Detection, Fast Characterization, Rapid Mapping and LongTerm Monitoring, edited for the SafeLand European project by Michoud, C., Abellán, A., Derron, M.-H., and Jaboyedoff, M., available at: http://www.safeland-fp7.eu, 2010

Sturzenegger, M. and Stead, D.: Quantifying discontinuity orientation and persistence on high mountain rock slopes and large landslides using terrestrial remote sensing techniques, Nat. Hazards Earth Syst. Sci., 9, 267-287, doi:10.5194/nhess-9-2672009, 2009.

Teza, G., Galgaro, A., Zaltron, N., and Genevois, R.: Terrestrial laser scanner to detect landslide displacement fields: a new approach, Int. J. Remote Sens., 28(16), 3425-3446, 2007.

Varnes, D. J.: Slope movement types and processes, in: Landslides: Analysis and Control, edited by: Schuster, R. L. and Krizek, R. J., Transportation Research Board (TRB), National Research Council, Washington, D.C., Special Report 176, 11-33, 1978.

Vilajosana, I., Suriñach, E., Abellán, A., Khazaradze, G., Garcia, D., and Llosa, J.: Rockfall induced seismic signals: case study in Montserrat, Catalonia, Nat. Hazards Earth Syst. Sci., 8, 805-812, doi:10.5194/nhess-8-805-2008, 2008.

Voegtle, T., Schwab, I., and Landes, T.: Influences of different materials on the measurement of a Terrestrial Laser Scanner (TLS), Proc. of the XXI Congress, The International Society for Photogrammetry and Remote Sensing, ISPRS2008, Vol. XXXVII, Commission V, 3-11 July 2008, Beijing, China, 1061-1066, 2008.

Zvelebill, J. and Moser, M.: Monitoring Based Time-prediction of rock falls: Three Case-Histories, Phys. Chem. Earth Pt. B, 26(2), 159-167, 2001. 